\title{
IMPLEMENTASI KEBIJAKAN BANTUAN LANGSUNG TUNAI DANA DESA BAGI MASYARAKAT MISKIN YANG TERDAMPAK COVID-19 DI DESA SIDOREJO KECAMATAN SAWAHAN KABUPATEN NGANJUK
}

\author{
*M. Daimul Abror ${ }^{1)}$ \\ 1)Prodi Administrasi Publik, Fakultas Ilmu Sosial \& Ilmu Politik, Universitas Kadiri, Indonesia \\ *Email Korespondensi : daimabror@unik-kediri.ac.id
}

\begin{abstract}
Abstrak
Penelitian ini mendeskripsikan, menganalisis dan menginterpretasikan implementasi Kebijakan Bantuan Langsung Tunai Dana Desa bagi masyarakat di desa Sidorejo, terutama masyarakat miskin terdampak Covid-19. Adapun metode penelitian yang digunakan yaitu metode kualitatif dengan pendekatan studi kasus. Hasil dari penelitian bahwa (1) implementasi kebijakan dalam perpektif pendekatan mentalitas keputusan dari pemerintah desa terkait dengan penentuan penetapan warga yang berhak menerima BLT Dana Desa didasarkan atas hasil musyawarah desa yang melibatkan Kepala Desa dan BPD. Selain itu juga didasarkan pada ketentuan dari pemerintah pusat bahwa penerima BLT DD bukan peserta PKH, namun realita di lapangan masih banyak warga penerima PKH yang menerima BLT DD. Sikap ini menunjukkan ada mentalitas yang menunjukkan dari pihak pemerintah desa kurang teliti dalam pendataan dan disisi lain mentalitas masyarakat yang suka memanfaatkan momentum tersebut untuk menambah kemanfaatan pribadi. (2) implementasi kebijakan dalam perpektif pendekatan sistem menunjukkan bahwa alur dan mekanisme pendataan sudah dijalankan sesuai dengan ketentuan yang berlaku, dimana sistem penyaluran BLT dana desa tahap I hingga Tahap IV sudah berjalan dengan baik. (3) implementasi kebijakan dalam perpektif pendekatan jejaring kerjasama menunjukkan bahwa masih ada miss understanding antara Pemerintah Desa sebagai implementor kebijakan BLT DD dengan masyarakat sebagai penerima BLT DD, dimana masih ditemukan mayarakat peserta program PKH yang ternyata masih menerima BLT DD.
\end{abstract}

Kata Kunci: Implementasi; Kebijakan; Bantuan Tunai Langsung; Dana Desa; Covid-19.

\begin{abstract}
This research describes, analyzes and interprets the implementation of the Village Fund Cash Direct Assistance Policy for the community in Sidorejo village, especially the poor community during the Covid-19 outbreak. The research method used is a qualitative method with a case study approach. The results of the research are that (1) the implementation of policies in the decision mentality approach from the village government is related to the determination of residents who are entitled to receive BLT Village Funds based on the results of village deliberations involving
\end{abstract}


the Village Head and BPD. In addition, it is also based on provisions from the central government that $B L T D D$ recipients are not $P K H$ participants, but the reality on the ground is that there are still many PKH recipients who receive BLT DD. This attitude shows that there is a mentality that shows that the village government is less careful in data collection and on the other hand the mentality of the people who like to take advantage of this momentum to increase personal benefits. (2) the implementation of the policy in the system approach approach shows that the flow and mechanism of data collection have been carried out in accordance with applicable regulations, where the phase I distribution system of village funds has been running well. (3) the implementation of the policy in the collaborative network approach shows that there is still a lack of understanding between the Village Government as the implementer of the BLT DD policy and the community as the recipient of the BLT DD, where there are still people who are participating in the PKH program who in fact still receive BLT DD. This shows a lack of awareness from the community and on the other hand the lack of a validation process from the village government.

Keywords: Implementation; Policy; Direct Cash Assistance; Village Funds; Covid-19.

\section{PENDAHULUAN}

Pandemi COVID-19 menekan perekonomian dari berbagai sudut, tidak terkecuali terhadap perekonomian desa. Untuk saat ini, dampak COVID-19 lebih dirasakan oleh masyarakat di perkotaan. Namun, mengingat pekerja musiman memiliki mobilitas cukup tinggi, dari desa ke kota lalu Kembali ke desa, wabah COVID-19 juga bisa merebak ke desa (Muzaqi et al., 2020). Kegiatan mudik menjelang Ramadhan dan Idul Fitri pada April dan Mei 2020 ini juga memperluas penyebaran COVID-19 di perdesaan. Dengan sumber daya ekonomi dan social yang dimilikinya, terutama Anggaran Pendapatan dan Belanja Desa (APBDes) dan dana desa, desa dapat berkontribusi dalam penanganan Covid-19.

Dana desa merupakan alokasi anggaran on budget yang dapat digunakan langsung untuk mendukung upaya mengurangi dampak COVID-19 di tingkat rumah tangga dan desa. Beberapa keunggulan dana desa d antaranya alokasi anggaran tersedia dalam Anggaran Pendapatan dan Belanja Negara; dapat dibuat menjadi program aksi cepat yang dapat segera dimulai; dapat melengkapi program lain untuk meminimalkan dampak social an ekonomi; tidak memerlukan system baru sehingga aparat desa bisa langsung bergerak karena sudah memahami system yang ada; dapat diarahkan untuk membangun legitimasi dan kredibilitas pemerintah desa melalui penyelesaian masalah secara local; serta sudah tersedianya system pemantauan, evaluasi dan pertanggungjwaban yang dapat dioptimalkan untuk menjamin akuntabilitas. 
Terbitnya Perppu No. 1/2020 memberikan instrument baru untuk meminimalkan dampak pandemic COVID-19 terhadap perekonomian desa. Pada pasal 2 Ayat (1) huruf (i) peraturan tersebut disebutkan bahwaperlu dilakukan pengutamaan penggunaan alokasi anggaran untuk kegiatan tertentu (refocusing), penyesuaian alokasi dan atau pemotongan atau penundaan penyaluran anggaran transfer ke daerah dan dana desa, dengan kriteria tertentu. Selanjutnya dalam penjelasan Perppu tersebut disebutkan bahwa yang dimaksud dengan "pengutamaan penggunaan dana desa" adalah dana desa dapat digunakan antara lain untuk bantuan langsung tunai bagi penduduk miskin di desa dan kegiatan penanganan Pandemi COVID-19. Dengan adanya pasal berikut penjelasannya tersebut, perlu dilakukan kajian bagaimana kebijakan tersebut dapat diterapkan dengan cepat dan menekan “jebakan moral” (moral hazard). (http://tnp2k.go.id)

Anggaran dana desa pada 2020 ditetapkan sebesar Rp. 72 triliun. Untuk kebutuhan BLT-D, dialokasikan 20-30 persen dari total dana desa. Pelaksanaan BLT-D setidaknya dapat diterapkan selama enam bulan dengan target penerima manfaat adalah rumah tangga. Target tersebut relevan ditetapkan mengingat Sebagian besar program nasional yang terkait dengan bantuan social merujuk pada penerima manfaat di tingkat rumah tangga, seperti Program Keluarga Harapan, Bantuan Pangan Nontunai, dan Bantuan Langsung Sementara Masyarakat / Bantuan Langsung Tunai.

Belakangan ini para Kepala Desa dibuat pusing oleh daftar penduduk desa yang berhak menerima Bantuan Langsung tunai Dana Desa (BLT DD). Pasalnya banyak desa yang mungkin jumlah penerima BLT yang memenuhi kriteria tidak sebanding dengan jatah anggaranyang diambil dari dana desa, karena jumlah penerima BLT jauh lebih besar dari anggaran yang tersedia. Jaring pengaman social baru ini menyasara 11 juta keluarga keluarga dengan total anggaran Rp. 22,4 triliun yang diambil dari total alokasi dana desa 2020 sebesar Rp. 71.19 triliun . Besaran dana yang disiapkan tiap desa berbeda-beda berkisar $25-35 \%$, tergantung jumlah dana desa yang diterima tahun ini.

Ketentuan dan mekanisme pendataan hingga pelaksanaan pemberia BLT DD tercantum dalam Peraturan Menteri Desa Nomor 6 Tahun 2020 yang diterbitkan 14 April 2020 tentang perubahan atas peraturan Menteri desa, pembangunan daerah tertinggal dan transmigrasi nomor 11 tahun 2019 tentang prioritas penggunaan dana desa tahun 2020. 
Peraturan tersebut mengubah Peraturan Menteri Desa Nomor 11 Tahun 2019 tentang Prioritas Penggunaan Dana Desa Tahun Anggaran 2020. Pasal 8A dalam aturan itu menetapkan beberapa syarat penerima bantuan, seperti keluarga yang kehilangan mata pencarian atau pekerjaan, belum terdata menerima berbagai bantuan soasila serta mempunyai anggota keluarga yang rentan sakit menahun atau kronis.

Sebelumnya, Menteri Desa dan PDTT juga menerbitkan Surat Edaran Nomor 8 Tahun 2020 tentang Desa Tanggap COVID-19 dan penegasan Padat Karya Tunia Desa. Dalam peraturan tersebut alokasi bantuan langsung tunai untuk pagu dana desa yang kurang dari Rp. 800 Juta ditetapkan 25 persen dari dana desa. Alokasi untuk desa dengan pagu Rp. 800 juta - 1,2 miliar sebesar 30 persen. Adapun desa dengan pagu diatas Rp. 1,2 miliarmendapat alokasi 35 persen. Skema ini bisa dikembangkan lebih dari 35 persen apabila dibutuhkan dengan persetujuan pemerintah di daerah.

Dengan di undangkannya Peraturan Menteri Desa dan Pembangunan Daerah Tertinggal dan Transmigrasi (Permendes PDTT) Nomor 6 Tahun 2020 tentang Perubahan Atas Peraturan Menteri Desa, Pembangunan Daerah Tertinggal dan TRansmigrasi Nomor 11 Tahun 2019 tentang prioritas Penggunaan Dana Desa Tahun 2020, maka menjadi dasar juridis dan implementatif Bantuan Langsung Tunai (BLT) kepada penduduk miskin di desa. Karenanya, diperlukan kesiapan dan kesigapan pemerintah desa untuk segera mendistribusikan BLT dimaksud secara tertib, adil dan tepat sasaran, tepat orang, tepat waktu, tepat proses dan tepat laporan administrasi.

Desa Sidorejo Kecamatan Sawahan Kabupaten Nganjuk merupakan salah satu desa di Indonesia yang masyarakatnya terkena dampak akibat Pandemi COVID-19, Sebagian besar masyarakat di des aini memiliki pekerjaan petani dan pekebun yang memasarkan hasil pertaniannya ke daerah lain atau di obyek wisata yang ada di daerah tersbut dalam 6 bulan terakhir omset hasil pertanian dan perkebunan seperti cengkih, duren, padi, alpukat berkurang dan berakibat rendahnya harga beli hasil tani dan kebun mereka. Dengan adanya aturan tersebut, pemerintah desa menganggarkan dana bantuan langsung sebesar $25 \%$ dari total anggaran dana desa yang akan diterima.

Adapun kriteria calon keluarga yang berhak menerima BLT Desa adalah keluarga miskin atau tidak mampu yang berdomisili di desa bersangkutan. Selain itu, dipastikan 
bahwa calon penerima bansos ini tidak termasuk ke dalam penerima bantuan Program Keluarga Harapan (PKH), kartu Sembako dan Kartu Prakerja. Pendataan calon penerima BLT desa, akan mempertimbangkan Data Terpadu Kesejahteraan Sosial (DTKS) dari Kementerian Sosial.

\section{TINJAUAN PUSTAKA}

Penelitian ini menggunakan landasan teori tentang Model MSN-Implementasi Kebijakan Publik yang dikembangkan oleh (Wahab, 2021). Dimana implementasi sebuah kebijakan public dapat dianalisis dengan menggunakan tiga pendekatan utama, yakni pendekatan Mentalis, pendekatan system, dan pendekatan jejaring kerjasama :

1. Pendekatan Mentalitas (Mentality Approach)

Pendekatan ini memiliki dimensi yang terwujud pada indikator focus: sikap, perilaku, dan tanggungjawab.

a. Sikap Pemerintah sebagai aparat pembuat/pengambil dan implementor kebijakan, sikap kalangan enterpreneur/Private Sector dan Civil Society, terwujud pada: i) Sikap spiritual, semua elemen baik pemerintah, swasta maupun masyarakat sipil harus semakin mengokohkan keimanan dan ketakwaan kepada Allah Swt, sebab apapun yang kita kerjakan akan dipertanggungjawabkan kepada-Nya. Sikap spritual itu dapat dideskripsikan dalam bentuk: a) menghargai, b) menghormati, dan c) menghayati ajaran agama yang dianut, dan ii) Sikap sosial, bahwa semua elemen baik pemerintah, swasta maupun masyarakat sipil harus semakin berakhlak mulia, mandiri, demokratis, dan bertanggung jawab. Sikap sosial dapat dideskripsikan dalam bentuk: a) jujur, b) disiplin, c) toleransi, d) gotong royong, e) santun, dan f) percaya diri. Sikap spiritual sebagai perwujudan dari penguatan interaksi vertikal dengan Tuhan Yang Maha Esa, sedangkan sikap sosial sebagai perwujudan eksistensi kesadaran dalam upaya mewujudkan harmoni kehidupan

b. Perilaku Pemerintah (aparat pembuat/pengambil dan implementor kebijakan), serta sikap kalangan enterpreneur/Private Sector dan Civil Society, yang dapat dideskripsikan dalam bentuk (Paisa et al., 2019): a) Memahami dan mengenali perilaku sesuai kode etik dimanapun beraktivitas, b) Melakukan tindakan yang 
konsisten dengan nilai dan keyakinannya, c) Bertindak berdasarkan nilai meskipun sulit untuk melakukan itu, dan d) Bertindak berdasarkan nilai walaupun ada resiko atau biaya yang cukup besar

c. Tanggungjawab Pemerintah sebagai aparat pembuat/pengambil dan implementor kebijakan, serta sikap kalangan enterpreneur/Private Sector dan Civil Society, yang dapat dideskripsikan dalam bentuk (Salsabila Firdausy dan Ummu Nur Hanifah, 2018): a) kemampuan melaksanakan tugas sesuai prosedur, b) kemampuan mengelola waktu, c) kesediaan menyelesaikan tugas dan d) kemampuan menanggung resiko

\section{Pendekatan Sistem (System Approach)}

Pendekatan sistem ini terwujud pada indikator fokus: sistem regulasi, system nilai budaya, dan sistem struktur dan fungsi organisasi (Sedarmayanti, 2004).

a. Sistem Regulasi yang dideskripsikan dalam bentuk sub sistem: a) kepentingan publik, b) partisipatif, c) produktif. Dalam hal ini pemerintah sebagai regulator dan juga sebagai implementor (aparatnya), meyakini bahwa regulasi yang dibentuk benar-benar untuk kepentingan publik, menggugah masyarakat sipil dan enterpreneur lebih partisipatif, serta regulasi juga untuk meningkatkan produktivitas layanan public secara transparan dan dapat dipertanggungjawabkan.

b. Sistem Nilai Budaya yang dideskripsikan dalam bentuk sub sistem : a) Kearifan lokal, b) Kekerabatan, dan c) Kegotong royong-an. Pemerintah (aparat pembuat/pengambil dan implementor kebijakan), serta kalangan enterpreneur/Private Sector dan Civil Society secara bersama mengokohkan dan menghormati sub sistem kearifan lokal berupa : adat budaya, bahasa, etnis dan sub etnis, menjaga kohesivitas kekerabatan serta ke-gotong-royong-an sebagai modal utama penggerak keberhasilan dan keberlanjutan pembangunan.

c. Sistem Struktur dan Fungsi Organisasi yang dideskripsikan dalam bentuk sub sistem (Sinungan, 2013): a) interaksi, b) interdependensi, c) integritas. Pemerintah (aparat pembuat/pengambil dan implementor kebijakan), serta kalangan enterpreneur/Private Sector dan Civil Society secara bersama menyadari akan pentingnya struktur dan fungsi organisasi dalam mengimplementasikan seluruh 
kebijakan program kemasyarakatan, pemerintahan dan pembangunan yang didukung oleh adanya saling keterhubungan antara pemerintah, masyarakat sipil dan enterpreneur (interaksi), serta saling adanya ketergantuan (interdependensi), berikut adanya keterpaduan antara pemerintah, masyarakat sipil dan enterpreneur dalam kerangka mencapai tujuan bernegara dan bermasyarakat

3. Pendekatan Jejaring Kerjasama (Networking Approach)

Pendekatan jejaring kerjasama ini ini terwujud pada indikator fokus: kemitraan strategis, sinergitas, dan simbiosis mutualisme (Polnaya \& Darwanto, 2015).

a. Kemitraan Strategis, yang dideskripsikan dalam bentuk sub sistem: a) kerjasama, b) kesetaraan, c) keterbukaan dan d) saling menguntungkan (memberikan manfaat). Pemerintah, Private Sector, dan Civil Society dalam menjalankan tugas dan kewajiban dalam perspektif implementasi kebijakan sudah seharusnya mengandalkan dan menghandakan kerjasama dalam spirit kesetaraan dan saling terbuka, serta saling memberikan manfaat antar sesama, dalam kerangka mewujudkan kepentingan bersama dalam membangun bangsa lebih utuh dan komprehensif.

b. Sinergitas adalah Membangun dan memastikan hubungan kerjasama internal yang produktif serta kemitraan yang harmonis dengan para pemangku kepentingan, untuk menghasilkan karya yang bermanfaat dan berkualitas yang dideskripsikan dalam bentuk sub sistem: a) Aspek kelembagaan, b) Kebijakan dan penganggaran program, c) Sumber daya manusia, d) Data dan informasi, dan e) strategi monev terhadap kebijakan dan program. Tujuan Sinergitas adalah mempengaruhi perilaku orang secara individu maupun kelompok saat saling berhubungan, melalui dialog dengan semua golongan, dimana persepsi, sikap dan opininya penting terhadap suatu kesuksesan. Pemerintah, Private Sector, dan Civil Society dalam menjalankan tugas dan kewajiban dalam perspektif implementasi kebijakan sudah seharusnya memperhatikan aspek kelembagaan, kebijakan dan penganggaran, sumber daya manusia, dukungan data dan informasi, serta strategi Monev yang secara efektif dilaksanakan. 
c. Simbiosis Mutualisme, hubungan antara dua pihak yang berbeda dan saling menguntungkan dalam aktivitas kemasyarakatan dan pembangunan, yang dideskripsikan dalam bentuk sub sistem: a) Saling membutuhkan, b) Saling menguntungkan, dan c) Saling mendukung. Pemerintah, Private Sector, dan Civil Society dalam menjalankan tugas dan kewajiban dalam perspektif implementasi kebijakan sudah seharusnya mengedepankan kehendak bersama untuk saling membutuhkan, saling menguntungkan dan saling mendukung dalam perspektif keberhasilan implementasi kebijakan publik.

\section{METODE PENELITIAN}

Penelitian ini merupakan penelitian kualitalif dengan pendekatan studi kasus. Teknik pengumpulan data dengan wawancara, observasi dan dokumentasi. Sedangkan Sumber data Primer diperoleh dari hasil wawancara dengan beberapa informan yang dianggap relevan dan memahami permasalahan yang ingin ditemukan dalam penelitian. Adapun informan-informan dalam penelitian ini adalah: Kepala Desa Sidorejo, Perangkat Desa Sidorejo, Kepala Badan Permusyawaratan Desa Sidorejo, dan Masyarakat Desa Sidorejo. Adapun sumber data sekunder diperoleh dari dokumen atau arsip desa sidorejo Kecamatan Sawahan Kabupaten Nganjuk dan literatur-literatur terkait implementasi Bantuan Langsung Tunai Dana Desa.

Analisis data yang digunakan dalam penelitian menggunakan analisis data model interaktif yang digagas oleh (Miles, 2014), meliputi: Kondensasi Data, dengan melakukan pengumpulan data melalui observasi dan wawancara langsung pada aktor-aktor yang terlibat dalam implementasi BLT DD. Penyajian Data, dengan memaparkan hasil temuan penelitian terkait tiga pendekatan utama dalam implementasi BLT DD, yakni pendekatan

mentalis, pendekatan system, dan pendekatan jejaring kerjasama. Penarikan Kesimpulan dan Verifikasi, dilakukan untuk menyimpulkan data-data atau informasi-informasi yang ditemukan selama penelitian terkait implementasi BLT DD dengan menggunakan tiga pendetan utama tersebut.

\section{HASIL DAN PEMBAHASAN}


Berdasarkan hasil penelitian di lapangan maka berikut disajikan data dan hasil pembahasannya sesuai dengan teori implementasi kebijakan public yang didasarkan pada tiga pendekatan utama, yakni pendekatan mentalis, pendekatan system, dan pendekatan jejaring kerjasama (Wahab, 2021)

1. Pendekatan Mentalis (Sikap, Perilaku, dan Tanggungjawab)

Menentukan pilihan bukanlah suatu persoalan yang gampang dan juga bukan hanya tebakan tetapi melalui suatu proses, sehingga dapat menemukan yang terbaik diantara yang baik atau yang terjujur diantara yang jujur atau kedua-duanya yang terbaik dan terjujur diantara yang baik dan jujur.

Bantuan Langsung Tunai Dana Desa (BLT-Dana Desa) adalah bantuan uang kepada keluarga miskin di desa yang bersumber dari Dana Desa untuk mengurangi dampak pandemi COVID-19. Adapun nilai BLTDana Desa adalah Rp. 600.000 setiap bulan untuk setiap keluarga miskin yang memenuhi kriteria dan diberikan selama 3 (tiga) bulan dan Rp. 300.000 setiap bulan untuk tiga bulan berikutnya. BLT-Dana Desa ini bebas pajak. Jika kebutuhan desa melebihi ketentuan maksimal yang dapat dialokasikan oleh desa, maka Kepala Desa dapat mengajukan usulan penambahan alokasi Dana Desa untuk Bantuan Langsung Tunai kepada Bupati/ Wali Kota. Usulan tersebut harus disertai alasan penambahan alokasi sesuai keputusan Musyawarah Desa Khusus (Musdesus).

Dalam rangka menentukan pilihan bagi penerima yang layak dan tidak layak penerima BLT dana desa pemerintah desa harus mengikuti Proses Validasi dan Penetapan Hasil Pendataan terlebih dahulu. Adapun prosesnya sebagai berikut:

a. Kepala Desa memfasilitasi BPD untuk melaksanakan musyawarah desa khusus dengan mengundang perwakilan masyarakat dan pihak lain yang terkait untuk membantu verifikasi dan validasi data terkait penentuan calon penerima BLT-Dana Desa.

b. Berdasarkan hasil musyawarah tersebut, Kepala Desa dan BPD menandatangani daftar keluarga miskin calon penerima BLT-Dana Desa. Merujuk kepada daftar tersebut, desa menyalurkan BLT-Dana Desa bulan pertama. 
c. Kepala Desa menyebarluaskan daftar calon penerima BLT-Dana Desa yang sudah disahkan kepada masyarakat baik melalui papan informasi di setiap dusun dan/atau di tempattempat yang strategis dan mudah dijangkau. Desa juga dapat memanfaatkan website desa atau Sistem Informasi Desa sebagai media informasi publik.

d. Jika ada keluhan dari masyarakat terhadap daftar calon penerima BLT-Dana Desa, maka desa bersama BPD memfasilitasi musyawarah desa untuk membahas keluhan tersebut dan menyepakati solusinya.

Perangkat desa yang juga merupakan gugus tugas panganganan covid 19 di desa Sidorejo mengatakan: "Dalam rangka menentukan calon penerima BLT dana desa yang tepat, kami harus mengikuti prosedur yang telah dikeluarkan oleh pemerintah pusat. Salah satu syarat penerima BLT dana desa adalah calon penerima bukanlah peserta program keluarga harapan $(\mathrm{PKH})$. Permasalahannya adalah terkadang pemerintah desa tidak mendeteksi masyarakat yang sudah menerima PKH dan tidak mengakuinya, hal tersebut kembali ke masyarakat, karena sebelumnya kami juga telah mensosialisasikan syarat penerima program BLT dana desa. Jadi kembali lagi ke masyarakat masing-masing, apalagi ditengah pandemic ini kita harus saling membantu satu sama lain.” Berdasarkan informasi yang didapat dari kementerian desa disebutkan bahwa Calon penerima BLTDana Desa adalah keluarga miskin baik yang terdata dalam Data Terpadu 13 Kesejahteraan Sosial (DTKS) maupun yang tidak terdata (exclusion error) yang memenuhi kriteria sebagai berikut:

a. Tidak mendapat bantuan PKH/BPNT/ pemilik Kartu Prakerja;

b. Mengalami kehilangan mata pencaharian (tidak memiliki cadangan ekonomi yang cukup untuk bertahan hidup selama tiga bulan ke depan);

c. Mempunyai anggota keluarga yang rentan sakit menahun/kronis. Tim pendata harus memastikan kelompok rentan seperti keluarga miskin yang dikepalai oleh perempuan, lansia, dan penyandang disabilitas terdata sebagai calon Keluarga Penerima Manfaat (KPM) BLT Dana Desa.

Berdasarkan hasil penelitian melalui data sekunder dan informasi yang berkompeten dibidangnya didapati jumlah penerima bantuan langsung tunai dana desa 
tahap I di desa Sidorejo berjumlah 103 kepala keluarga Rp. 600.000 dan Rp. 300.000 pada tahap kedua yang perinciannya dapat dilihat pada tabel berikut ini:

Tabel Rincian penerima BLT Dana Desa di Desa Sidorejo

\begin{tabular}{|c|c|c|c|c|}
\hline NO & Jaga & Jumlah Penerima & Tahap I (Rp.) & Tahap II (Rp.) \\
\hline 1 & I & 28 & Rp. 600.000 & Rp. 300.000 \\
\hline 2 & II & 24 & Rp. 600.000 & Rp. 300.000 \\
\hline 3 & III & 21 & Rp. 600.000 & Rp. 300.000 \\
\hline 4 & IV & 30 & Rp. 600.000 & Rp. 300.000 \\
\hline
\end{tabular}

Menurut Tokoh Masyarakat setempat mengatakan bahwa : Bantuan langsung tunai menurutnya sudah sangat membantu bagi masyarakat terutama yang terkena dampak covid 19. Namun dalam penentuan penerimannya beliau selaku tokoh masyarakat disini masih menerima pengaduan bahwa ada beberapa masyarakat yang sebenarnya tidak layak menerima tapi tetap menerima, selaku tokoh masyarakat beliau menanyakan hal tersebut kepada Kepala Desa dan beliau mengatakan bahwa tidak ada unsur kesengajaan apabila hal tersebut jadi, kalaupun ada karena tidak disengaja atau ada masyarakat yang tidak jujur. Terutama yang sudah penerima PKH dan tidak mengakuinya. Sedangkan menurut kepala desa, dalam system seperti ini tentunya juga bisa salah apalagi manusia, dalam hal adanya aduan bahwa ada masyarakat yang sebenarnya tidak layak menerima dan mereka menerima itu hanya unsur human error saja atau ada mis komunikasi dengan masyarakat, dan beliau bisa memastikan bahwa tidak ada unsur nepotisme didalamnya.

Dari hasil ini diketahui bahwa ketepatan menentukan pilihan pemerintah desa sudah bekerja sesuai dengan prosedur, mengenai adanya dugaan nepotisme dalam penentuan penerima BLT Dana Desa telah di bantah oleh kepala desa dengan tegas dan juga berdasarkan hasil data dilapangan menyatakan demikian.

2. Pendekatan Sistem (Regulasi, Nilai Budaya, dan Struktur \& Fungsi Organisasi)

Untuk melaksanakan suatu kegiatan atau program maka perencanaan dalam menentukan waktu mutlak diperlukan. Waktu yang digunakan secara tepat akan mempengaruhi tingkat keefektivitasan suatu program dalam mencapai tujuan. Untuk mengetahui ketepatan waktu penyaluran bantuan langsung tunai dana desa, terlebih dahulu dipaparkan mengenai mekanisme pendataan calon penerima BLT dana Desa. 
Mekanisme dan Alur Pendataan Calon Penerima BLT-Dana Desa, dapat ditentukan sendiri oleh desa dengan mengikuti kriteria yang ditetapkan, melaksanakan pendataan secara transparan dan adil serta dapat dipertanggungjawabkan secara hukum. Desa dapat menggunakan data desa sebagai acuan, serta menggunakan DTKS sebagai referensi penerima PKH, BPNT, serta data Dinas Ketenagakerjaan untuk identifikasi penerima bantuan Kartu Prakerja. Jika data penerima JPS tersebut tidak tersedia, maka desa bisa menggunakan data rekapitulasi penerima bantuan dari pendamping program jaring pengaman sosial. Berikut adalah mekanisme pendataan keluarga miskin dan rentan calon penerima BLT-Dana Desa serta penetapan hasil pendataannya:

- Proses Pendataan

1. Perangkat Desa menyiapkan data desa yang mencakup profil penduduk desa berdasarkan usia, kesejahteraan, pendidikan, kesehatan, dan disabilitas.

2. Kepala Desa membentuk dan memberikan surat tugas kepada Relawan Desa dan/atau Gugus Tugas COVID-19 untuk melakukan pendataan keluarga miskin calon penerima BLT-Dana Desa.

3. Jumlah pendata minimal 3 orang dan jika lebih harus berjumlah ganjil.

4. Melakukan pendataan di tingkat Rukun Tetangga (RT) atau Rukun Warga (RW) dengan menggunakan formulir pendataan pada Lampiran 2, atau di tingkat dusun dengan menggunakan aplikasi Desa Melawan COVID-19. Seluruh kegiatan pendataan harus memperhatikan protokol kesehatan.

- Proses Konsolidasi dan Verifikasi

1. Relawan Desa dan/atau Gugus tugas COVID-19 menghimpun hasil pendataan dari RT, RW atau dusun dan melakukan verifikasi serta tabulasi data. Dalam proses verifikasi syarat penerima BLT Dana Desa, hal yang dilakukan adalah:

a) Keluarga miskin penerima PKH atau penerima BPNT dikeluarkan dari daftar calon penerima BLT-Dana Desa. Data penerima bantuan PKH dan BPNT ada dalam DTKS yang bisa didapat dari Dinas Sosial kabupaten/kota atau dari Pendamping PKH. 
b) Keluarga miskin penerima Kartu Prakerja dikeluarkan dari daftar calon penerima BLTDana Desa. Data penerima kartu tersebut bisa didapatkan dari Dinas Ketenagakerjaan kabupaten/kota.

c) Mengidentifikasi keluarga miskin dan rentan untuk diprioritaskan menjadi penerima BLTDana Desa.

d) Melakukan verifikasi status kependudukan calon penerima BLT-Dana Desa berdasarkan data administrasi kependudukan (adminduk) yang dimiliki oleh desa atau dari Dinas Kependudukan dan Pencatatan Sipil (Dinas Dukcapil) kabupaten/kota.

2. Relawan Desa dan/atau Gugus Tugas COVID-19 memastikan keluarga miskin dan rentan seperti perempuan kepala keluarga, warga lanjut usia, penyandang disabilitas menjadi prioritas/ tidak boleh terlewat.

3. Setiap melakukan verifikasi keluarga miskin dan mengidentifikasi keluarga miskin dan rentan, Relawan Desa dan/atau Gugus Tugas COVID-19 perlu mengambil foto dan mencantumkan lokasi tempat tinggalnya secara manual dan digital (share location) jika memungkinkan.

4. Bila ditemukan keluarga miskin calon penerima BLT-Dana Desa yang tidak memiliki Nomor Induk Kependudukan (NIK), petugas pendata mencatat dan memberikannya kepada kasi pemerintahan atau petugas khusus di desa, untuk selanjutnya dibuatkan Surat Keterangan Domisili. Calon penerima BLT-Dana Desa yang hanya memiliki surat keterangan tersebut kemudian dicatat dan diinformasikan ke petugas adminduk di desa jika ada, atau ke kecamatan atau langsung ke Dinas Dukcapil untuk mendapatkan layanan adminduk.

5. Hasil verifikasi dan pendataan baru disampaikan oleh Relawan Desa dan/atau Gugus Tugas COVID-19 kepada Kepala Desa.

Daftar calon penerima BLT-Dana Desa dilaporkan dan disahkan oleh Bupati/Wali Kota, atau dapat diwakilkan ke Camat. Untuk penyaluran bulan ke dua, desa harus memastikan bahwa data penerima BLT-Dana Desa harus sudah disahkan.

Efektivitas merupakan suatu hal yang berkaitan erat dengan produktivitas dan efisiensi. Sebagaimana yang dikemukakan oleh (Prastyo, 2015) produktivitas merupakan 
suatu ukuran mengenai apa yang diperoleh dengan apa yang diberikan. Penggunaan waktu dalam program pembangunan yaitu penyaluran BLT dana desa didesa talaitad tersebut selesai tepat waktu sebagaimana yang telah ditentukan dalam perencanaan.

Informasi yang didapat tersebut diperkuat dengan observasi langsung dilapangan dan diikuti dengan diskusi kecil dengan beberapa masyarakat desa yang juga menerima bantuan langsung tunai dana desa tersebut. Dan mayoritas masyarakat yang ditemui menguatkan pernyataan tersebut. Dimana alur dan mekanisme pendataan sudah dijalankan sesuai dengan ketentuan yang berlaku. Dari hasil tersebut, dapat di simpulkan bahwa dari pendekatan system penyaluran BLT dana desa tahap I hingga Tahap IV sudah berjalan dengan baik.

3. Pendekatan Jejaring Kerjasama (kemitraan Strategis, Sinergitas, dan Simbiosis Mutualisme

Dalam rangka memastikan ketepatan sasaran yakni dalam penyaluran Bantuan Langsung Tunai Dana Desa, pemerintah pusat telah mengeluarkan mekanisme serta tugas dari masing-masing tingkatan pemerintah dari pemerintah pusat sampai yang ada di daerah. Untuk menjalankan proses penyaluran BLT-Dana Desa ini perlu dilakukan koordinasi lintas sektor maupun lintas tingkatan pemerintahan yang baik. Berikut ini adalah koordinasi dan pembagian tugas serta kewenangan dalam pembinaan dan pengawasan pendataan calon penerima BLTDana Desa.

\section{a. Pemerintah Pusat}

1. Melaksanakan koordinasi dan memberikan arahan kebijakan pelaksanaan pendataan calon penerima BLT-Dana Desa.

2. Melaksanakan pembinaan dan pengawasan pelaksanaan pendataan calon penerima BLTDana Desa.

b. Pemerintah Daerah Provinsi

1. Melakukan pemantauan, pembinaan, dan pengawasan pelaksanaan kegiatan terkait pendataan BLT-Dana Desa melalui: 
- Peningkatan kapasitas dan bimbingan teknis kepada Dinas PMD kabupaten/ kota, kecamatan (Camat, Pembina Teknis Pemerintahan Desa atau PTPD dan Pendamping Desa) serta pemerintah desa/ BPD; dan

- Pemantauan, pembinaan dan pengawasan langsung terhadap pelaksanaan BLT-Dana Desa.

2. Memetakan ketersediaan bantuan sosial dan jaring pengaman baik yang berasal dari pemerintah pusat dan daerah serta mengatur jumlah target sasaran serta waktu penyalurannya. Dengan membaca hasil pendataan desa yang diverifikasi oleh pemerintah daerah kabupaten/ kota, pemerintah daerah provinsi dapat menentukan jumlah sasaran bantuan sosial provinsi yang belum dapat dipenuhi oleh BLT-Dana Desa, bantuan sosial kabupaten/kota dan pemerintah pusat.

c. Pemerintah Daerah Kabupaten/ Kota

1. Bupati/Wali Kota mengarahkan koordinasi antar dinas terkait, khususnya Dinas Sosial, Dinas PMD, Camat, dan Kepala Desa dalam pemanfaatan DTKS sesuai dengan Peraturan Menteri Sosial Nomor 5 Tahun 2019 tentang Pengelolaan Data Terpadu Kesejahteraan Sosial.

2. Bupati/Wali Kota mengarahkan koordinasi antar dinas terkait, khususnya Dinas Sosial dan Dinas Dukcapil dalam proses pemutakhiran NIK pada DTKS sesuai dengan arahan Komisi Pemberantasan Korupsi (KPK) dan Surat Edaran Kementerian Sosial.

3. Bupati/Wali Kota bersama dengan Bappeda, Dinas Sosial dan instansi terkait berkoordinasi dengan provinsi terkait jumlah target sasaran dan waktu penyaluran berbagai bantuan sosial yang ada di daerahnya (memastikan tidak adanya tumpang tindih data dan penerima BLT-Dana Desa dan bantuan sosial lainnya).

4. Bupati/Wali Kota menyebarluaskan informasi pendataan penerima BLTDana Desa dan melakukan pengawasan pendataan calon penerima BLTDana Desa. 
5. Bupati/Wali Kota melibatkan organisasi masyarakat sipil untuk aktif memfasilitasi dan/ atau mengawasi pelaksanaan BLT-Dana Desa.

6. Dinas PMD dan dinas terkait lainnya melakukan peningkatan kapasitas dan/atau memberikan bantuan teknis kepada kecamatan (Camat, PTPD dan Pendamping Desa) dan pemerintah desa/BPD terkait pendataan calon penerima BLT-Dana Desa.

7. Jika memungkinkan, Dinas Sosial bekerja sama dengan desa melakukan verifikasi dan validasi secara cepat dengan melibatkan Pusat Kesejahteraan Sosial (Puskesos) serta potensi dan sumber kesejahteraan sosial di kecamatan. Proses pendataan DTKS di kabupaten/kota mengikuti Peraturan Menteri Sosial Nomor 5 Tahun 2019 tentang Pengelolaan Data Terpadu Kesejahteraan Sosial.

8. Dinas Kependudukan dan Pencatatan Sipil menyediakan data penduduk berdasarkan NIK kepada Bappeda dan desa untuk dibandingkan dengan DTKS.

9. Aparat Pengawasan Intern Pemerintah (APIP) secara berjenjang memastikan agar pelaksanaan penanggulangan COVID-19 melalui APB Desa (secara keseluruhan), dan secara khusus pendataan calon penerima BLT-Dana Desa dilakukan secara efektif, efisien, transparan, dan akuntabel.

d. Kecamatan

1. Membantu Bupati/Wali Kota melakukan verifikasi daftar usulan kepala keluarga miskin dan rentan calon penerima BLT-Dana Desa yang diusulkan Kepala Desa.

2. Camat memantau dan mengevaluasi pelaksanaan pendataan calon penerima BLT-Dana Desa.

3. Tim kecamatan (Camat, PTPD dan Pendamping Desa) memfasilitasi, mendampingi dan membimbing pemerintah desa dan atau Relawan Desa dan/atau Gugus Tugas COVID-19 melakukan percepatan pendataan dan penyaluran BLT-Dana Desa. 
Selanjutnya dalam rangka pengaduan mengenai Bantuan Langsung Tunai dana desa, pemerintah pusat mengeluarkan mekanisme dimana Pemerintah Desa bekerja sama dengan BPD bersama Relawan Desa dan/atau Gugus Tugas COVID-19, menyiapkan saluran pengaduan dan aspirasi yang dapat dimanfaatkan oleh warga untuk menyampaikan keluhan terkait dengan pelaksanaan BLT-Dana Desa. Selanjutnya saluran aspirasi tersebut berupa informasi nomor telepon, Whatsapp, kotak saran dan/atau SID yang terintegrasi dengan pelaporan supra desa. Masyarakat juga dapat menyampaikan keluhan/ aduan/saran melalui saluran yang dikelola oleh pemerintah pusat, pemerintah daerah, atau instansi terkait lainnya.

\section{KESIMPULAN DAN SARAN}

Dari hasil analisis diatas, maka kesimpulan dari penelitian ini mencakup tiga hal, yakni (1) implementasi kebijakan Bantuan Langsung Tunai Dana Desa (BLT DD) ditinjau dari pendekatan mentalitas menunjukkan bahwa masih ditemukan fenomena dimana penerima BLT DD bukan peserta PKH masih banyak yang menerima BLT DD. Sikap ini menunjukkan indikasi terhadap mentalitas dari pihak pemerintah desa kurang teliti dalam pendataan dan disisi lain mentalitas masyarakat yang suka memanfaatkan momentum tersebut untuk menambah kemanfaatan pribadi. (2) implementasi kebijakan BLT DD ditinjau dari pendekatan sistem menunjukkan bahwa alur dan mekanisme pendataan sudah dijalankan sesuai dengan ketentuan yang berlaku, dimana sistem penyaluran BLT dana desa tahap I hingga Tahap IV sudah berjalan dengan baik. (3) implementasi kebijakan BLT DD ditinjau dari pendekatan jejaring kerjasama menunjukkan bahwa masih ada miss understanding antara Pemerintah Desa sebagai implementor kebijakan BLT DD dengan masyarakat sebagai penerima BLT DD, dimana masih ditemukan mayarakat peserta program $\mathrm{PKH}$ yang ternyata masih menerima BLT DD. Hal ini menunjukkan kurang adanya kesadaran dari pihak masyarakat dan disisi lain kurang adanya proses validasi yang terukur dari pihak pemerintah desa.

Dari kesimpulan yang tersaji diatas, maka peneliti menyarankan perlu adanya perbaikan mentalitas baik dari pihak pemerintah desa maupun masyarakat. Perbaikan mentalitas pemerintah desa dapat diprogramkan pendidikan dan pelatihan yang 
melibatkan pakar penyelenggaraan pemerintahan yang professional dan juga perlu dari pakar agama supaya para aparatur pemerintah desa memiliki hard skill dan soft skill yang mampu meningkatkan kapasitas dan mentalitas para aparatur pemerintah. Sedangkan perbaikan mentalitas bagi masyarakat perlu adanya edukasi yang diprogrankan oleh pemerintah desa guna memberikan pemahaman atas hak dan kewajiban terkait bantuan tunai langsung yang diberikan oleh Negara.

\section{REFERENSI}

Miles. (2014). Qualitative Data Analysis, A Methods Sourcebook. UI-Press.

Muzaqi, A. H., Yanuarita, H. A., Suwarno, S., \& Hanum, F. (2020). PENDAMPINGAN MASYARAKAT ADAPTASI KEHIDUPAN BARU DALAM MENCIPTAKAN KAWASAN TANGGUH BENCANA COVID-19 STUDI PADA FASILITAS UMUM KOTA KEDIRI. Jurnal Abdi Masyarakat, 4(1).

Paisa, L., Gosal, R., \& Monintja, D. (2019). Etika Pemerinthan Dalam Meningkatkan Kinerja Aparatur Sipil Negara. JURNAL EKSEKUTIF, 3(3).

Peraturan Menteri Desa Nomor 11 Tahun 2019 tentang Prioritas Penggunaan Dana Desa Tahun Anggaran 2020

Peraturan Menteri Desa Nomor 6 Tahun 2020 yang diterbitkan 14 April 2020 tentang perubahan atas peraturan menteri desa, pembangunan daerah tertinggal, dan transmigrasi nomor 11 tahun 2019 tentang prioritas penggunaan dana desa tahun 2020

Peraturan Pemerintah Pengganti Undang-Undang Nomor 1 Tahun 2020 tentang Kebijakan Keuangan Negara dan Stabilitas Sistem Keuangan untuk Penanganan Pandemi Corona Virus Disease 2019 (COVID-19) dan/atau Dalam Rangka Menghadapi Ancaman yang Membahayakan Perekonomian Nasional dan/atau Stabilitas Sistem Keuangan

Polnaya, G. A., \& Darwanto. (2015). Pengembangan Ekonomi Lokal Untuk Meningkatkan Daya Saing Pada Ukm Ekonomi Kreatif Batik Bakaran Di Pati, Jawa Tengah. Jurnal Bisnis Dan Ekonomi, 22(Vol 22, No 1 (2015): Vol. 22 No. 1 2015), $1-10$.

Prastyo, Y. A. (2015). Pengaruh Budaya Perusahaan Dan Lingkungan Kerja Terhadap Kinerja Karyawan (Studi Kasus Pada PT. Telekomunikasi Indonesia, Tbk Witel Jatim Selatan Malang). Jurnal Administrasi Bisnis, 24(2).

Salsabila Firdausy dan Ummu Nur Hanifah. (2018). PERMASALAHAN MANAJEMEN KINERJA DI INDONESIA DAN UPAYA KEMENTERIAN PANRB UNTUK MENGATASINYAitle. DEPUTI BIDANG REFORMASI BIROKRASI AKUNTABILITAS APARATUR DAN PENGAWASAN. 
Sedarmayanti. (2004). Good governance (kepemerintahan yang baik): bagian kedua: membangun sistem manajemen kinerja guna meningkatkan produktivitas menuju good governance (kepemerintahan yang baik). Mandar Maju.

Sinungan, M. (2013). Produktivitas Apa Dan Bagaimana (Cetakan ke). Bumi Aksara.

Surat Edaran Nomor 8 Tahun 2020 tentang Desa Tanggap Covid-19 dan Penegasan

Wahab, S. A. (2021). Analisis kebijakan: dari formulasi ke penyusunan model-model implementasi kebijakan publik. Bumi Aksara. 